\title{
Pharmacogenetics in Neuroblastoma: What Can Already Be Clinically Implemented and What Is Coming Next?
}

\author{
Gladys G. Olivera ${ }^{1,2} \mathbb{D}$, Andrea Urtasun ${ }^{3,4}$, Luis Sendra ${ }^{1,2, * \mathbb{D}}$, Salvador F. Aliño ${ }^{1,2, *}$, Yania Yáñez ${ }^{3} \mathbb{D}$, \\ Vanessa Segura ${ }^{3}$, Pablo Gargallo ${ }^{3}$ (D) Pablo Berlanga ${ }^{5}$, Victoria Castel ${ }^{3}$ (D) Adela Cañete ${ }^{3}$ and \\ María José Herrero ${ }^{1,2}$ D
}

1 Pharmacogenetics and Gene Therapy Platform, IIS La Fe, Hospital La Fe, Torre A-Lab 4.03, Av. Fernando Abril Martorell 106, 46026 Valencia, Spain; gladys_guadalupe@iislafe.es (G.G.O.); maria.jose.herrero@uv.es (M.J.H.)

2 Department of Pharmacology, Faculty of Medicine, University of Valencia, Av. Blasco Ibáñez 15, 46010 Valencia, Spain

3 Pediatric Oncology Unit, Hospital Universitario y Politécnico La Fe, Av. Fernando Abril Martorell 106, 46026 Valencia, Spain; andrea.urtasun@sjd.es (A.U.); yanyez_yan@gva.es (Y.Y.); segura_van@gva.es (V.S.); pablogt28@gmail.com (P.G.); castel_vic@gva.es (V.C.); canyete_ade@gva.es (A.C.)

4 Oncohematology Department, Hospital Sant Joan de Deu, Passeig Sant Joan de Déu 2, Esplugues de Llobregat, 08950 Barcelona, Spain

5 Department of Pediatric and Adolescent Oncology, Institute Gustave Roussy Center, Rue Edouard Vaillant 114, 94800 Villejuif, France; pablo.berlanga@gustaveroussy.fr

* Correspondence: luis.sendra@uv.es (L.S.); alino@uv.es (S.F.A.)

check for updates

Citation: Olivera, G.G.; Urtasun, A.; Sendra, L.; Aliño, S.F.; Yáñez, Y.; Segura, V.; Gargallo, P.; Berlanga, P.; Castel, V.; Cañete, A.; et al.

Pharmacogenetics in Neuroblastoma: What Can Already Be Clinically Implemented and What Is Coming Next? Int. J. Mol. Sci. 2021, 22, 9815. https://doi.org/10.3390/ijms22189815

Academic Editor: Fabio Morandi

Received: 17 August 2021

Accepted: 8 September 2021

Published: 10 September 2021

Publisher's Note: MDPI stays neutral with regard to jurisdictional claims in published maps and institutional affiliations.

Copyright: (C) 2021 by the authors. Licensee MDPI, Basel, Switzerland. This article is an open access article distributed under the terms and conditions of the Creative Commons Attribution (CC BY) license (https:// creativecommons.org/licenses/by/ $4.0 /)$.

\begin{abstract}
Pharmacogenetics is one of the cornerstones of Personalized Precision Medicine that needs to be implemented in the routine of our patients' clinical management in order to tailor their therapies as much as possible, with the aim of maximizing efficacy and minimizing toxicity. This is of great importance, especially in pediatric cancer and even more in complex malignancies such as neuroblastoma, where the rates of therapeutic success are still below those of many other types of tumors. The studies are mainly focused on germline genetic variants and in the present review, state of the art is presented: which are the variants that have a level of evidence high enough to be implemented in the clinic, and how to distinguish them from the ones that still need validation to confirm their utility. Further aspects as relevant characteristics regarding ontogeny and future directions in the research will also be discussed.
\end{abstract}

Keywords: SNP (single nucleotide polymorphism); chemotherapy; drug label; clinical implementation guidelines

\section{Introduction}

Neuroblastoma (NB), the most common solid extracranial malignancy during childhood, has its origin in the adrenal medulla or paraspinal ganglia (sympathetic nervous system) during the period of development [1] and shows great phenotypic heterogeneity: some infants have spontaneous regression of the tumor while others present disease progression event after intensive multimodal treatment [2].

Although translational and clinical research has evolved considerably in recent years, in the cases requiring treatment, the prognosis of children with High-Risk Neuroblastoma (HR-NB) remains very poor. Despite the fact that it only represents around $8 \%$ of all pediatric cancers, it causes $15 \%$ of all deaths due to cancer in children. Barely $40 \%$ of the children diagnosed survive longer than 5 years [3,4]. Indeed, when metastatic relapse occurs, there is no curative treatment, and the overall survival rate after relapse is around 12 months. Thus, the lack of effective treatment continues to be a major concern for pediatric oncologists. Another relevant aspect to take into account is that $>50 \%$ of survivor children 
face sequelae derived from chemotherapy toxicity along with their life, reinforcing the idea that chemotherapy needs to be optimized [5].

At this point, doctors need tools to apply the best available treatment to each patient in terms of maximizing efficacy and minimizing toxicity. Pharmacogenetics (PGx), one of the cornerstones of Precision Personalized Medicine, is the study of variants in the patient's germline (constitutive) DNA related to the efficacy and safety of drugs. Tumor (somatic) genetic variants can also be considered, but they are out of the scope of this review. The most abundant genetic variants influencing PGx are the Single Nucleotide Polymorphisms (SNPs), accounting for approximately $90 \%$ of human genome variability $[6,7]$. However, key variants influencing PGx also include genomic insertions, deletions, and repeats, as well as genetic copy number variations (CNVs).

The state of the art in PGx is divided into two categories: there is an already welldefined group of relevant associated drug-SNP pairs whose level of scientific-clinical evidence offers the highest quality, robust enough to be implemented in routine clinical practice. On the other side, drug-SNP pairs with less core evidence require further translational research to validate their usefulness in the real clinical setting.

In this review, the current situation of both categories is presented. The first part describes the genetic variants that can already be implemented in the clinical setting, and doctors can use them to adjust the NB chemotherapeutic treatment. After that, a view of the main variants that are currently under investigation to validate or discard their utility in NB treatment is presented. The last part of the review describes further considerations under a translational research perspective. The drugs included are those employed for (1) Induction treatments: cisplatin, vincristine, carboplatin, etoposide, cyclophosphamide, topotecan, doxorubicin; (2) Consolidation: busulfan, melphalan; and finally (3) Maintenance therapy and others: 13-cis-retinoic acid (isotretinoin), dinutuximab beta, interleukin 2, granulocyte and macrophage-colonies stimulating factor (GM-CSF) and radiotherapy.

\section{Pharmacogenetic Variants for Clinical Implementation}

Relevant institutions and scientific societies worldwide agree on the use of three main pillars as the references to identify those genetic variants with the highest level of evidence to be implemented in the clinic. These three cornerstones are the indications of drug regulatory agencies, PharmGKB (Pharmacogenomics Knowledge Base) [8], and relevant international consortia of experts developing clinical guidelines for PGx implementation.

\subsection{Drug Regulatory Agencies}

Regulatory agencies as the US Food and Drug Administration (FDA), the European Medicines Agency (EMA), the Pharmaceuticals and Medical Devices Agency from Japan (PMDA), and Health Canada Santé Canada (HCSC), amongst others [9-12], recommend in the Drug Labels a genetic test prior to the use of many drugs they approve. The Drug Label indicates if the test is required, recommendable, actionable, or simply informative [8]. At this point, it must be remarked that any requirement of a specific action in the drug label must be considered a legal requirement, with consequences in the case of disregard.

\subsection{PharmGKB Clinical Annotations}

PharmGKB, is a free access database created, curated, and managed by the University of Stanford and funded by US National Institutes of Health (NIH) and National Institute of General Medicine Science (NIGMS) [8]. It compiles most of the existing PGx information, from many different databases, including PubMed, under a Creative Commons license. It counts with a group of experts working on the dissemination of knowledge about the impact of human genetic variation on drug responses and on the translation of PGx into clinical practice. In fact, the website (www.pharmgkb.org, accessed on 25 June 2021) includes not only the information of its own curation from published data, the 'Clinical Annotations', but also that of the Drug Labels and the reports by Experts Consortia. 
Clinical Annotations are the curated results obtained by PharmGKB's experts after publications review for assigning different levels of evidence in the association of a genetic variant with efficacy, toxicity, metabolism/pharmacokinetics, and dosage of a drug. This 'Level of Evidence' ranks from 1 to 4, being 1 the one meeting the highest criteria. Level 2 is tagged as "moderate", while 3 and 4 are "low" and "unsupported," respectively. Very recently, these criteria have incorporated a new scoring system.

\subsection{Clinical Implementation Guidelines}

These are drug adjustment guidelines published by experts' consortia to provide recommendations about what actions the prescriber should consider according to patient genotype. The main consortia are the Clinical Pharmacogenetics Implementation Consortium (CPIC) [13], the Royal Dutch Association for the Advancement of PharmacyPharmacogenetics Working Group (DPWG) [14], but also other professional and scientific societies [15]. PharmGKB also compiles this information on the website and provides links to the complete articles under the section 'Prescribing Info-Clinical Guideline Annotations'.

According to these three pillars, Table 1 shows the revised drugs that meet at least one criterion of the three pillars: PGx information in the drug label according to Drug Regulatory Agencies, PharmGKB Clinical Annotations with Level of Evidence 1 or 2, Clinical Implementation Guideline elaborated by an international expert Consortium. It must be underlined that, as previously stated, PharmGKB has just performed relevant modifications, beginning approximately on 25 March 2021. For caution, in this table, we have considered the immediate previous information regarding Clinical Annotations, but the current modifications have been marked.

Three drugs have genetic recommendations in Drug Labels according to different regulatory agencies, but these recommendations are not strictly PGx. They are mainly related to the use for which the drug is intended, its clinical indication, and the genes to be analyzed are not in the constitutive DNA of the patient but in the tumor. These drugs are Busulfan (FDA: $A B L 1$ and $B C R$ genes), 13-cis-retinoic acid (not isotretinoin, but tretinoin has required testing for PML and RARA genes in the FDA Drug Label, the same in Health Canada Santé Canada Label, and also, but at an informative level, in the Japanese regulatory agency). The same situation applies to vincristine but, apart from Drug Label, it has a Clinical Annotation.

Dinutuximab contains information in the FDA label regarding $M Y C N$ in the clinical trials performed.

In this sense, only the indications for TPMT regarding Cisplatin are really related to germline variants and a toxic event that could be prevented: ototoxicity.

Regarding Clinical Implementation Guidelines, we have this kind of source for two of the revised drugs: cisplatin and doxorubicin [16,17]. The recommendations of the CPNDS for the PGx-guided use of these drugs are summarized in Table 2. 


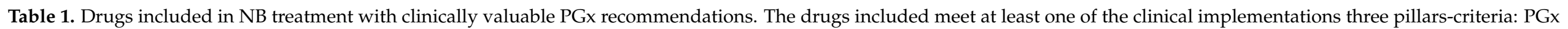

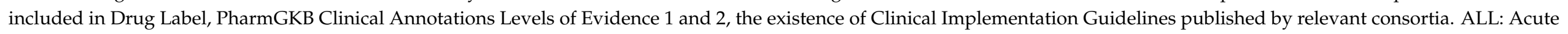

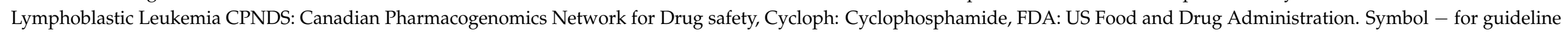
and drug label: lack of information.

\begin{tabular}{|c|c|c|c|c|c|c|c|}
\hline Drug & Gene & SNP & $\begin{array}{l}\text { Reference } \\
\text { Genotype }\end{array}$ & $\begin{array}{c}\text { Risk } \\
\text { Genotype }\end{array}$ & $\begin{array}{l}\text { ClinAnnot: } \\
\text { Level }\end{array}$ & $\begin{array}{l}\text { Recommendation for } \\
\text { the Risk Genotype }\end{array}$ & $\begin{array}{l}\text { Guideline/ } \\
\text { Drug Label }\end{array}$ \\
\hline Busulfan & & & & & & & $\begin{array}{l}\text {-/FDA: Actionable } \\
A B L 1, B C R \text { (in ALL) }\end{array}$ \\
\hline \multirow{5}{*}{ Carboplatin } & $E R C C 1$ & rs11615 & GG & $\mathrm{AA}, \mathrm{AG}$ & 2B: E,T & $\begin{array}{c}\text { Moderate risk of inefficacy } \\
\text { and toxicity }\end{array}$ & \multirow{5}{*}{$-1-$} \\
\hline & GSTP1 & rs1695 & GG & AA, AG & 2A: $\mathrm{T}$ & Moderate risk of toxicity & \\
\hline & MTHFR & rs1801133 & AA & AG, GG & 2A: E & Moderate risk of inefficacy & \\
\hline & XRCC1 & rs25487 & $\mathrm{CC}$ & $\mathrm{CT}, \mathrm{TT}$ & 2B: $\mathrm{E}$ & Moderate risk of inefficacy & \\
\hline & $E R C C 1$ & rs3212986 & $\mathrm{AA}$ & $\mathrm{AC}, \mathrm{CC}$ & $2 \mathrm{~B}: \mathrm{T}$ & Moderate risk of toxicity & \\
\hline \multirow{3}{*}{ Cycloph. } & TP53 & rs1042522 & $\mathrm{CC}$ & CG, GG & 2B: E,T & \multirow{3}{*}{$\begin{array}{c}\text { Moderate risk of inefficacy } \\
\text { and toxicity } \\
\text { Moderate risk of inefficacy } \\
\text { Moderate risk of inefficacy } \\
\text { and toxicity }\end{array}$} & \multirow{3}{*}{$-1-$} \\
\hline & SOD2 & rs4880 & $\mathrm{AA}$ & AG, GG & 2B: E & & \\
\hline & GSTP1 & rs1695 & $\mathrm{AA}, \mathrm{AG}$ & GG & 2A: E,T & & \\
\hline \multirow{7}{*}{ Cisplatin } & TP53 & rs1042522 & $\mathrm{CC}$ & CG, GG & 2B: E,T & $\begin{array}{l}\text { Moderate risk of inefficacy } \\
\text { and toxicity }\end{array}$ & \multirow{7}{*}{$\begin{array}{c}\text { CPNDS: TPMT/ } \\
\text { FDA: Informative } \\
\text { TPMT }\end{array}$} \\
\hline & MTHFR & rs1801133 & AA & AG, GG & 2A: E & Moderate risk of inefficacy & \\
\hline & GSTP1 & rs1695 & AA & AG, GG & 2B: $\mathrm{T}$ & Moderate risk of toxicity & \\
\hline & GSTP1 & rs1695 & GG & $\mathrm{AG}, \mathrm{AA}$ & 2A: E & Moderate risk of inefficacy & \\
\hline & XRCC1 & rs25487 & $\mathrm{CC}$ & $\mathrm{CT}, \mathrm{TT}$ & 2B: E & Moderate risk of inefficacy & \\
\hline & $E R C C 1$ & rs3212986 & AA & $\mathrm{AC}, \mathrm{CC}$ & $2 \mathrm{~B}: \mathrm{T}$ & Moderate risk of toxicity & \\
\hline & $E R C C 1$ & rs11615 & GG & $\mathrm{AA}, \mathrm{AG}$ & 2B: E,T & $\begin{array}{l}\text { Moderate risk of inefficacy } \\
\text { and toxicity }\end{array}$ & \\
\hline Doxorubicin & NQO1 & rs1800566 & GG & AA, AG & 2A: E & Moderate risk of inefficacy & $\begin{array}{c}\text { CPNDS: RARG, } \\
\text { SLC28A3, } \\
\text { UGT1A6/- }\end{array}$ \\
\hline Etoposide & DYNC2H1 & rs716274 & AA & AG, GG & 2B: $\mathrm{T}$ & Moderate risk of toxicity & $-1-$ \\
\hline Vincristine & CEP72 & rs924607 & $\mathrm{CC}, \mathrm{CT}$ & TT & 2B: $\mathrm{T}$ & Moderate risk of toxicity & $\begin{array}{c}\text { - /FDA: } \\
\text { Required ABL1, } \\
B C R \text { (in ALL) }\end{array}$ \\
\hline
\end{tabular}

Note: the Clinical Annotations included in this table have been changed to Level 3 after new updates at www.pharmgkb.org from 25 March 2021. 
Table 2. Summary of recommendations provided in the CPNDS guidelines for cisplatin and doxorubicin.

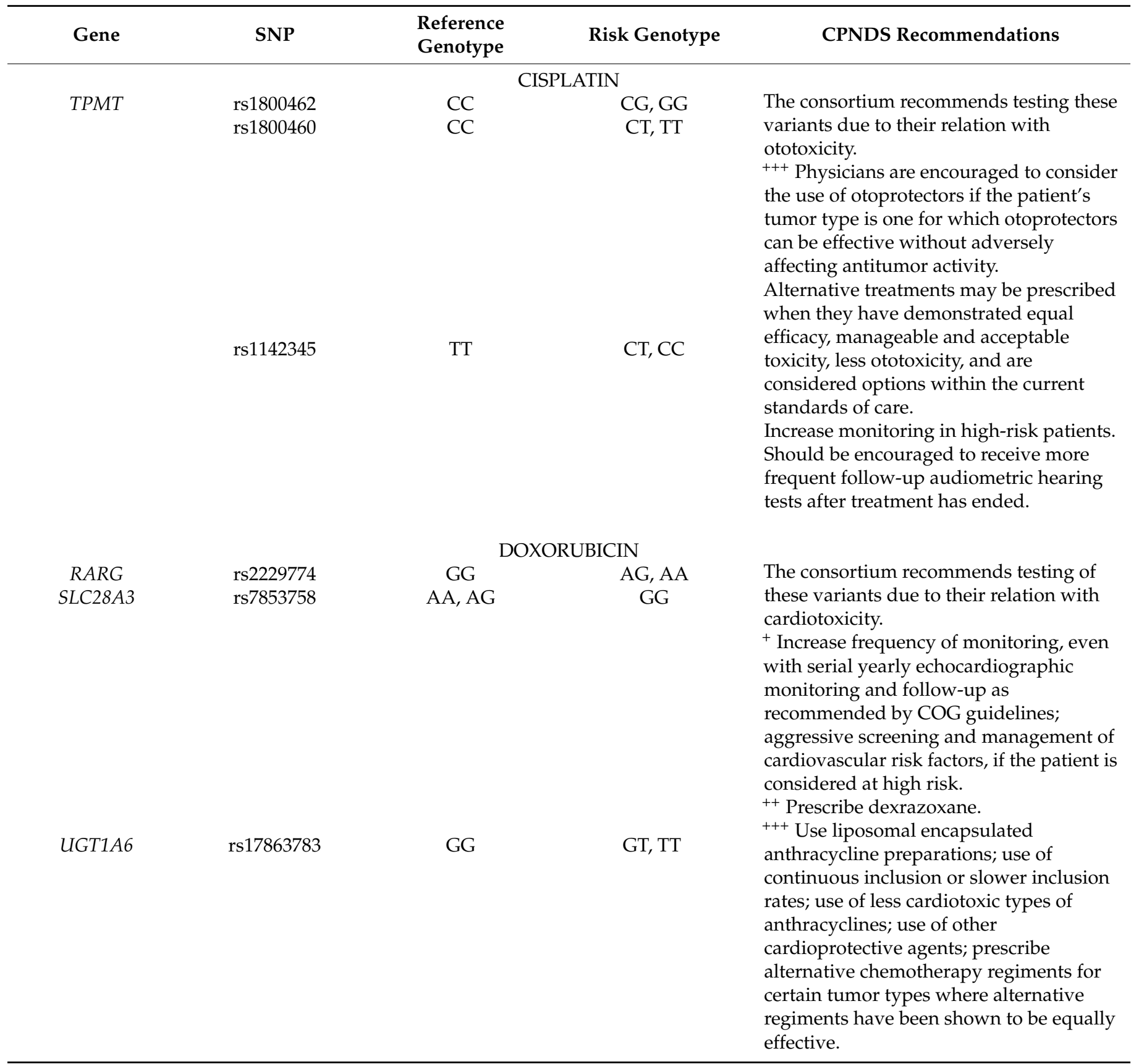

CPNDS: Canadian Pharmacogenomics Network for Drug Safety. Grading scheme used for clinical practice guidelines: ${ }^{+}$Level A corresponds to a high level of evidence (benefits clearly overcome the risks); ${ }^{++}$level B is a recommendation with lower scientific evidence level based on expert opinion; and ${ }^{+++}$level $C$ is mainly based in expert's opinion to be used in research context. SNP: single nucleotide polymorphisms, COG: Children's Oncology Group.

\section{Pharmacogenetic Variants under Investigation Regarding NB Therapy}

Regarding research, there is still a lot of work to conduct. There are multitudes of SNPs whose influence on drug response was proposed but is not yet sufficiently tested, and, therefore, validation is needed. As shown in Table 1, only a few drugs from the group included in this review have one pillar (at least) supporting their implementation in the clinical setting. However, for the rest of the drugs, many of the genes coding the transporters, metabolizing enzymes, and targets of these drugs are already known, and 
research should be addressed to identify the implications of the SNPs in those genes on the safety and efficacy of those drugs.

Table 3 shows a compilation of the most promising SNPs that are under research, according to the literature search. In most of the manuscripts, the studies have been performed with the combinations of drugs that are currently used in chemotherapy regimens. For clarity, we have searched for literature with results attributable to single drugs and not to combinations of them. Another criterion for the selection, in most cases, has been the known relationship between the gene and the drug in terms of transport, metabolism, and/or mechanism of action.

Our knowledge about the genes involved in the mechanism of action, transport, and metabolism of the drugs is in many cases much more limited than expected. This happens not only with the newest drugs, but also with the classic chemotherapy that has been employed for decades. Therefore, focusing our attention on the SNPs contained in the genes responsible for the fate of the drug in our organism is not always easy. In addition, interactions exist, and these can happen immediately or with mid-long term effects, difficult to predict. All these together lead to "difficult to explain findings," except for a much-reduced group of genes directly related to specific events. For example, SNPs in genes such as MTHFR, TP53, or VDR have been correlated with overall survival and event-free survival in PGx studies of NB patients, whereas these genes are not directly involved in the body routes of the chemotherapeutic drugs employed. In our group's experience, rs1801133 in MTHFR $(p=0.02)$ and rs1544410 in VDR $(p=0.006)$ added an important predictive value for overall survival to the $M Y C N$ status, with a more accurate patients sub stratification than using MYCN alone [58-60].

If we check the bibliography, the most robust results should be reported from clinical trials, but these are obtained in predesigned and very much controlled situations different from the real clinical setting. For this reason, studies should be performed respecting the clinical reality, including concomitant treatments, especially considering that in pediatric oncology, many of the children participate in clinical trials evaluating their treatment and impeding them to participate in another specific for pharmacogenetics $[61,62]$. 
Table 3. Candidate SNPs and genes to evaluate regarding the efficacy and toxicity of the drugs in Neuroblastoma (based in PharmGKB and the included references).

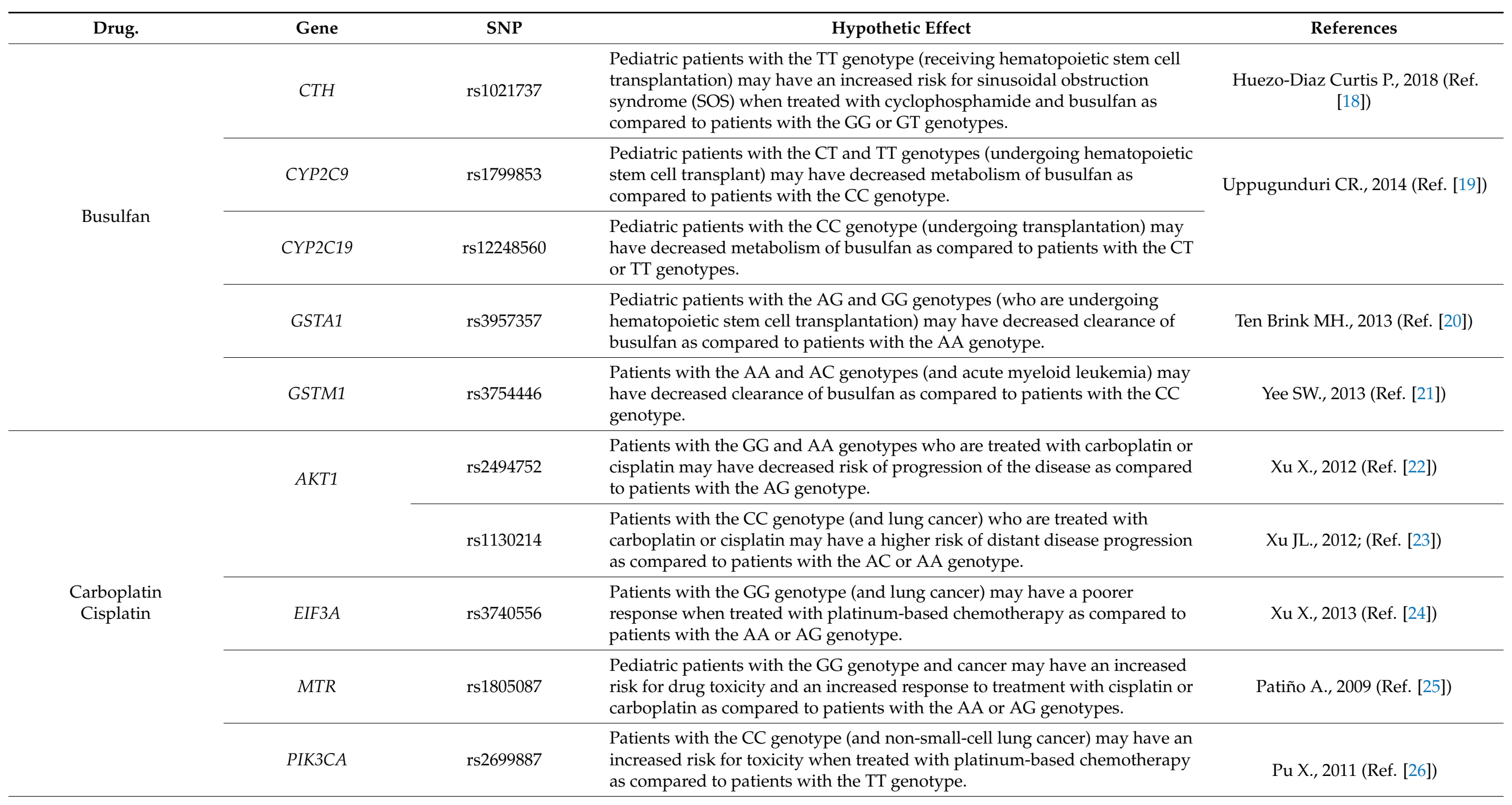


Table 3. Cont.

\begin{tabular}{|c|c|c|c|c|}
\hline Drug. & Gene & SNP & Hypothetic Effect & References \\
\hline & PTEN & rs2299939 & $\begin{array}{l}\text { Patients with the AA genotype (and non-small-cell lung cancer) may have an } \\
\text { increased risk for toxicity when treated with platinum-based chemotherapy } \\
\text { as compared to patients with the AC or CC genotype. }\end{array}$ & \\
\hline & SLC31A1 & rs7851395 & $\begin{array}{l}\text { Patients with the AA genotype may have increased overall survival when } \\
\text { treated with carboplatin or cisplatin (in people with Non-Small-Cell Lung } \\
\text { Carcinoma) as compared to patients with genotypes AG or GG. }\end{array}$ & Xu X., 2012 (Ref. [22]) \\
\hline & $\begin{array}{l}\text { Unknown } \\
\text { (Intronic) }\end{array}$ & rs2498804 & $\begin{array}{l}\text { Patients with the CC genotype (and non-small-cell lung cancer) may have an } \\
\text { increased risk of distant disease progression when treated with } \\
\text { platinum-based chemotherapy as compared to patients with the AA or AC } \\
\text { genotypes. }\end{array}$ & Pu X., 2011 (Ref. [26]) \\
\hline \multirow{5}{*}{ Cyclophosph. } & $A B C B 1$ & rs1045642 & $\begin{array}{l}\text { Allele } \mathrm{G} \text { is associated with an increased risk of death when treated with } \\
\text { cyclophosphamide in combination with other drugs, (in patients with } \\
\text { osteosarcoma) as compared to allele A. }\end{array}$ & Caronia D., 2011 (Ref. [27]) \\
\hline & $A B C C 4$ & rs9561778 & $\begin{array}{l}\text { Patients with the TT or GT genotypes (and breast cancer) who are treated } \\
\text { with cyclophosphamide may have an increased risk of } \\
\text { neutropenia/leukopenia and gastrointestinal toxicity, as compared to } \\
\text { patients with the GG genotype. }\end{array}$ & Low SK., 2009 (Ref. [28]) \\
\hline & \multirow{3}{*}{ CYP2B6 } & rs7254579 & $\begin{array}{l}\text { Patients (with lupus) and the CC or CT genotypes may have decreased } \\
\text { metabolism of cyclophosphamide, resulting in decreased concentrations of } \\
\text { active cyclophosphamide metabolite as compared to patients with TT } \\
\text { genotype. }\end{array}$ & \multirow[t]{2}{*}{ Su W., 2016 (Ref. [29]) } \\
\hline & & rs4802101 & $\begin{array}{l}\text { Patients with the CC genotype may have decreased metabolism of } \\
\text { cyclophosphamide, resulting in decreased concentrations of active } \\
\text { cyclophosphamide metabolites and decreased risk of gastrointestinal toxicity, } \\
\text { or leukopenia, as compared to patients with the CT or TT genotypes. }\end{array}$ & \\
\hline & & rs8192709 & $\begin{array}{l}\text { (Recipients of HLA-identical hematopoietic stem cell transplantation) with } \\
\text { the TT or CT genotypes (and leukemia) may have an increased risk for } \\
\text { hemorrhagic cystitis when treated with cyclophosphamide compared to } \\
\text { patients with the CC genotype. }\end{array}$ & Rocha V., 2009 (Ref. [30]) \\
\hline
\end{tabular}


Table 3. Cont.

\begin{tabular}{|c|c|c|c|c|}
\hline Drug. & Gene & SNP & Hypothetic Effect & References \\
\hline & & rs2279343 & $\begin{array}{l}\text { Patients with the GG or AG genotypes (who have received a hematopoietic stem } \\
\text { cell transplant) and are treated with cyclophosphamide may have an increased } \\
\text { risk for oral mucositis as compared to patients with the AA genotype. }\end{array}$ & \\
\hline & & rs3745274 & $\begin{array}{l}\text { (Leukemia patients who are) recipients (of HLA-identical hematopoietic stem } \\
\text { cell transplantation) from donors with the GG genotype may have an increased } \\
\text { risk of developing veno-occlusive disease of the liver when treated with } \\
\text { cyclophosphamide as compared to donor cells with the GT or TT } \\
\text { genotype.Patients with the GG or GT genotypes (and Breast Cancer) who are } \\
\text { treated with cyclophosphamide and doxorubicin may be more likely to require a } \\
\text { reduction in dose as compared to patients with the TT genotype. }\end{array}$ & Bray J., 2010 (Ref. [31]) \\
\hline & CYP2C19 & rs4244285 & $\begin{array}{l}\text { Patients with the GG genotype (and Systemic Lupus Erythematosus) who are } \\
\text { treated with cyclophosphamide may have increased metabolism of } \\
\text { cyclophosphamide, leading to higher concentrations of the active metabolite and } \\
\text { an increased risk of toxicity (ovarian, gastrointestinal, or hematological) as } \\
\text { compared to patients with the AA and AG genotype. }\end{array}$ & Su W., 2016 (Ref. [29]) \\
\hline & СУР3A4 & rs2740574 & $\begin{array}{l}\text { Premenopausal patients with the TT genotype (and breast cancer) who are } \\
\text { treated with cyclophosphamide may have a shorter period before } \\
\text { chemotherapy-induced ovarian failure compared to patients with the CC or CT } \\
\text { genotype. }\end{array}$ & Su HI., 2010 (Ref. [32]) \\
\hline Dinutuximab & & & $\begin{array}{l}\text { SNPs reducing or impairing the expression of GD2 could impede Dinutuximab } \\
\text { efficacy. }\end{array}$ & $\begin{array}{l}\text { Chen RL., } 2000 \\
\text { Greenwood KL., } 2018 \\
\quad \text { (Refs. [33,34]) }\end{array}$ \\
\hline \multirow{4}{*}{ Doxorubicin } & $A B C B 1$ & $\begin{array}{l}\text { rs1045642 } \\
\text { rs2032582 } \\
\text { rs1128503 }\end{array}$ & $\begin{array}{l}\text { Patients harboring the CC-GG-CC genotypes had significantly lower peak } \\
\text { plasma concentrations of doxorubicinol compared to patients who had TT-TT-TT } \\
\text { genotypes. }\end{array}$ & Lal S., 2008 (Ref. [35]) \\
\hline & $A B C C 1$ & rs45511401 & $\begin{array}{l}\text { Patients with the TT or GT genotypes (and non-Hodgkin lymphoma) who are } \\
\text { treated with doxorubicin may have an increased risk for cardiotoxicity as } \\
\text { compared to patients with the GG genotype. }\end{array}$ & \multirow{3}{*}{ Wojnowski L., 2005 (Ref. [36]) } \\
\hline & \multirow[t]{2}{*}{$A B C C 2$} & rs8187710 & $\begin{array}{l}\text { Patients with the AA or AG genotypes (and non-Hodgkin lymphoma) who are } \\
\text { treated with doxorubicin may have an increased risk of cardiotoxicity as } \\
\text { compared to patients with the GG genotype. }\end{array}$ & \\
\hline & & rs17222723 & $\begin{array}{l}\text { Patients with the AA or AT genotypes (and non-Hodgkin lymphoma) who are } \\
\text { treated with doxorubicin may have an increased risk of cardiotoxicity as } \\
\text { compared to patients with the TT genotype. }\end{array}$ & \\
\hline
\end{tabular}


Table 3. Cont.

\begin{tabular}{|c|c|c|c|c|}
\hline Drug. & Gene & SNP & Hypothetic Effect & References \\
\hline & CBR1 & rs9024 & $\begin{array}{l}\text { Patients with the GG genotype may have increased clearance of doxorubicin } \\
\text { and decreased exposure to doxorubicin compared to patients with the AG } \\
\text { genotype. }\end{array}$ & Lal S., 2008 (Ref. [37]) \\
\hline & CBR3 & rs8133052 & $\begin{array}{l}\text { Patients with the AA genotype (and breast cancer) who are treated with } \\
\text { doxorubicin may have decreased metabolism of doxorubicin and may have } \\
\text { greater tumor reduction, but may also have increased severity of neutropenia } \\
\text { as compared to patients with the GG genotype. }\end{array}$ & Fan L., 2008 (Ref. [38]) \\
\hline & GSTA1 & rs3957357 & $\begin{array}{l}\text { Patients with the GG and AG genotypes (and soft tissue sarcoma) may have } \\
\text { a shorter progression-free survival time when treated with doxorubicin as } \\
\text { compared to patients with the AA genotype. }\end{array}$ & Gelderblom H., 2014 (Ref. [40]) \\
\hline & GSTP1 & rs1695 & $\begin{array}{l}\text { Patients with osteosarcoma and the GG or AG genotypes may be at an } \\
\text { increased risk of developing leukopenia when treated with doxorubicin as } \\
\text { compared to patients with the AA genotype. }\end{array}$ & Windsor RE., 2012 (Ref. [41]) \\
\hline Etoposide & & & $\begin{array}{l}\text { All these relevant pharmacogenes } A B C B 1, A B C C 3, C Y P 3 A 4, C Y P 3 A 5, G S T P 1 \text {, } \\
\text { UGT1A1, are known to be relevant in etoposide pharmacokinetics, thus } \\
\text { studies } \\
\text { validating their main SNPs regarding the drug's toxicity and efficacy are } \\
\text { needed. }\end{array}$ & $\begin{array}{l}\text { Relling M.V., 1994; Zelcer N., 2001 } \\
\text { Huang RS.,2007 (Refs. [42-44]) }\end{array}$ \\
\hline GM-CSF & & & $\begin{array}{l}\text { Human GM-CSF receptor beta chain gene could be a good candidate to } \\
\text { investigate } \\
\text { the role of SNPs that could interfere the activation of the receptor by the drug. }\end{array}$ & Shen Y., 1992 (Ref. [45]) \\
\hline Interleukin2 & & & $\begin{array}{l}\text { SNPs in the gene coding for IL } 2 \text { receptor could be very informative to assess } \\
\text { the response to this treatment. }\end{array}$ & $\begin{array}{l}\text { Ladenstein R., 2018; YamaneB.H., } \\
\text { 2009; Shusterman S., } 2019 \text { (Refs. } \\
\text { [46-48]) }\end{array}$ \\
\hline
\end{tabular}


Table 3. Cont.

\begin{tabular}{|c|c|c|c|c|}
\hline Drug. & Gene & SNP & Hypothetic Effect & References \\
\hline Melphalan & & & $\begin{array}{l}A B C B 1 \text { and GSTP1 are relevant pharmacogenes that seem to be involved in } \\
\text { melphalan pharmacokinetics. Exploring their main SNPs could be of interest. }\end{array}$ & $\begin{array}{l}\text { Karkey M.A., } 2005 \text { and Hodges } \\
\text { L.M., } 2011 \text { (Refs. [49,50]) }\end{array}$ \\
\hline \multirow[b]{3}{*}{ Radiotherapy } & $C D K 1$ & rs10711 & $\begin{array}{l}\text { Patients with the GG or GT genotypes may have increased risk of } \\
\text { pneumonitis when treated with radiotherapy (lung cancer) as compared to } \\
\text { patients with genotype TT. }\end{array}$ & Pu X., 2014 (Ref. [51]) \\
\hline & PRKCE & rs11125035 & $\begin{array}{l}\text { Patients with the AA genotype may have increased risk of esophagitis when } \\
\text { treated with radiotherapy as compared to patients with genotype TT or AT. }\end{array}$ & Pu X., 2014 (Ref. [51]) \\
\hline & TANC1 & $\begin{array}{c}\text { rs10497203 } \\
\text { rs264631 } \\
\text { rs264651 } \\
\text { rs6432512 } \\
\text { rs264588 } \\
\text { rs264663 } \\
\text { rs7582141 }\end{array}$ & $\begin{array}{l}\text { Patients with the CC or AC/CG or GG/GG/CT or TT/AA or AC/CT or } \\
\text { TT/GT or TT genotypes, respectively in the referred SNPs (left column) (and } \\
\text { prostate cancer) who are treated with radiotherapy may have an increased } \\
\text { risk of late stage toxicity as compared to patients with the other possible } \\
\text { genotypes. }\end{array}$ & Fachal L., 2014 (Ref. [52]) \\
\hline Topotecan & $A B C G 2$ & rs4148157 & $\begin{array}{l}\text { Pediatric patients with the GG genotype (and brain tumors) may have } \\
\text { decreased absorption and lower concentrations of topotecan compared to } \\
\text { patients with the AA and AG genotypes. }\end{array}$ & Roberts J.K.,2016 (Ref. [53]) \\
\hline \multirow{3}{*}{ Vincristine } & $A B C B 1$ & rs1045642 & $\begin{array}{l}\text { Pediatric patients with the AA or AG genotypes (and acute lymphoblastic } \\
\text { leukemia) who are treated with vincristine may have a decreased likelihood } \\
\text { of event-free survival as compared to patients with the GG genotype. }\end{array}$ & Ceppi F.,2014 (Ref. [54]) \\
\hline & & rs4728709 & $\begin{array}{l}\text { Pediatric patients with the GG genotype (and acute lymphoblastic leukemia) } \\
\text { who are treated with vincristine may have an increased risk of grade 1-2 } \\
\text { neurotoxicity as compared to patients with the AA or AG genotypes. }\end{array}$ & Ceppi F.,2014 (Ref. [54]) \\
\hline & & & $\begin{array}{l}\text { CYP3A5 seems to be the main metabolizing enzyme for vincristine, thus } \\
\text { analyzing its main SNPs could be of interest }\end{array}$ & Egbelakin A.,2011 (Ref. [55]) \\
\hline \multirow[b]{2}{*}{ Isotretinoin } & $L E P$ & rs7799039 & These SNPs seem to correlate with the lipid disorders caused by the drug. & Khabour O.F.,2018 (Ref. [56]) \\
\hline & & & $\begin{array}{l}\text { Other SNPs in relevant genes related to the mechanism of action of the drug } \\
\text { could shed light for decreasing adverse side effects and increasing efficacy: } \\
R X R A, J A K 2, C D C 25 C\end{array}$ & Lee J.J,2011 (Ref. [57]) \\
\hline
\end{tabular}




\section{Further Consideration for a Perspective on NB PGx Translational Research \\ 4.1. The Role of Ontogeny in NB Pharmacogenetics}

The statement that children are not small adults is valid, particularly in pediatric clinical PGx. In order to offer children the optimal treatment, it is important not only to know the characteristics of the particular disease but also to integrate the changes of normal growth and development with their impact on the ontogeny of pharmacokinetic and pharmacogenomic factors. There are several age-related anatomic and physiological changes that have been found to influence drug ADME (Absorption, Distribution, Metabolism and Excretion) processes, such as differences in fat proportion in the body, gastric $\mathrm{pH}$ evolution, renal development, etc., but some of them are directly linked to the expression and role of relevant pharmacogenes. For instance, the activity of ABCB1 (P glycoprotein) and ABCG2, two of the most extensively studied ATP-binding cassette (ABC) transporters are decreased in the neonatal period $[63,64]$. Regarding metabolism, CYP3A7 shows the highest activity in the liver during embryonic, fetal, and newborn stages. After that, its activity declines, and other CYPs take the main roles. CYP3A4 appears during the first week after birth, reaching approximately $30-40 \%$ of adult activity by the first month and full adult activity by the 6 th month of life. Its activity increases so much that it reaches $120 \%$ of the adults between 1 and 4 years of age, decreasing to normal adult levels after puberty [65-67]. In the case of CYP1A2, its expression is delayed until 3 months after birth. Regarding Phase II enzymes, as UGT1A family, it is remarkable that UGT1A1 starts to increase at birth and does not reach adult levels since 3-6 months later; and that UGT1A6 and UGT1A9 activity levels are smaller in people younger than 10 years old in comparison with adults [67].

\subsection{What Else Do We Need to Take into Account? Research Integrating Epigenomics and Metabolomics}

The next goal is complementing PGx with two other relevant technologies that must undoubtedly be integrated: Epigenomics and Metabolomics. Explained in a very simple way, Epigenetics will deal with the study of the methylation status of the promoters of certain pharmacogenes as a mechanism of higher regulation that, above the nucleotide sequence of DNA, will determine whether a gene is really being expressed or not $[68,69]$. Metabolomics, also in a simplistic manner for this context, could characterize the plasma presence of metabolites corresponding to the drugs administered to the patients to check if the drugs have been effectively metabolized or not [70]. Complementing pharmacogenetics with the other two Omics techniques must help understand relevant questions: phenomena occurring in the patients that represent an upper layer of complexity for understanding the patients' real response to drugs. For instance, metabolic pathways that are switched on when the main metabolic route is "off" or hyper/hypomethylation phenomena that regulate the expression of genes, masking potential effects of the nucleotide sequence. In order to understand the real characteristics of each patient, integration of all this information by means of very advanced Biostatistics, Systems Biology, Pharmacology, and Artificial Intelligence will be required.

\section{Conclusions}

PGx knowledge needs to be implemented in the clinical routine of NB patients to support a more personalized approach regarding chemotherapy. The field is divided, with drug-genetic variants with a high level of scientific and clinical evidence and many more drug-SNP pairs needing further research in real patient contexts in order to validate their effects. The available literature regarding those associations is in many cases scarce and old, and the results have not been confirmed or updated. Thus, we need to put our efforts into this type of research. Meanwhile, those associations with high levels of evidence should be assessed in all our patients with the aim of providing the clinician with an additional tool to modify the treatment, if possible, and/or to be alert to increased risks of immediate or late toxicities. The current scenario provides data on relationships between SNP-drugs, but the reality is different most of the time due to the use of a combination of drugs. Thus, 
we need to validate the proposed "one-to-one" relationships in the real clinical context because interactions do exist, and the expected effects of concrete SNPs could not be the same in the context of polytherapy.

Author Contributions: Conceptualization, S.F.A., L.S. and M.J.H.; methodology, M.J.H., P.B., P.G.; investigation, G.G.O., A.U., Y.Y.; resources, V.S., G.G.O.; data curation, M.J.H., A.C., V.C.; writingoriginal draft preparation, G.G.O., L.S., M.J.H.; writing-review and editing, S.F.A., M.J.H.; visualization; funding acquisition, A.C., S.F.A., M.J.H. All authors have read and agreed to the published version of the manuscript.

Funding: This manuscript was elaborated while the last author was financially supported by Asociación Pablo Ugarte and research conducted under the support of Fundación Mutua MadrileñaAyudas a la Investigación Científica en Salud 2016.

Data Availability Statement: The data reported is contained in the referenced papers as well as in PharmGKB website (www.pharmgkb.org).

Acknowledgments: We would like to thank Desirée Ramal for her support to our research always.

Conflicts of Interest: The authors declare no conflict of interest.

\section{References}

1. Tolbert, V.P.; Coggins, G.E.; Maris, J.M. Genetic susceptibility to neuroblastoma. Curr. Opin. Genet. Dev. 2017, 42, 81-90. [CrossRef] [PubMed]

2. Hero, B.; Simon, T.; Spitz, R.; Ernestus, K.; Gnekow, A.K.; Scheel-Walter, H.G.; Schwabe, D.; Schilling, F.H.; Benz-Bohm, G.; Berthold, F. Localized infant neuroblastomas often show spontaneous regression: Results of the prospective trials NB95-S and NB97. J. Clin. Oncol. 2008, 26, 1504-1510. [CrossRef] [PubMed]

3. Park, J.R.; Bagatell, R.; Cohn, S.L.; Pearson, A.D.; Villablanca, J.G.; Berthold, F.; Burchill, S.; Boubaker, A.; McHugh, K.; Nuchtern, J.G.; et al. Revisions to the international neuroblastoma response criteria: A consensus statement from the National Cancer Institute clinical trials planning meeting. J. Clin. Oncol. 2017, 35, 2580-2587. [CrossRef]

4. Morgenstern, D.A.; Pötschger, U.; Moreno, L.; Papadakis, V.; Owens, C.; Ash, S.; Pasqualini, C.; Luksch, R.; Garaventa, A.; Canete, A.; et al. Risk stratification of high-risk metastatic neuroblastoma: A report from the HR-NBL-1/SIOPEN study. Pediatr. Blood Cancer 2018, 65, e27363. [CrossRef] [PubMed]

5. Clemens, E.; van der Kooi, A.L.F.; Broer, L.; van Dulmen-den Broeder, E.; Visscher, H.; Kremer, L.; Tissing, W.; Loonen, J.; Ronckers, C.M.; Pluijm, S.M.F.; et al. The influence of genetic variation on late toxicities in childhood cancer survivors: A review. Crit. Rev. Oncol. Hematol. 2018, 126, 154-167. [CrossRef]

6. Ross, C.J.D.; Visscher, H.; Rod Rassekh, S.; Castro-Pastrana, L.I.; Shereck, E.; Carleton, B.; Hayden, M.R. Pharmacogenomics of serious adverse drug reactions in pediatric oncology. J. Popul. Ther. Clin. Pharmacol. 2011, 18, 134-151.

7. Conyers, R.; Devaraja, S.; Elliott, D. Systematic review of pharmacogenomics and adverse drug reactions in paediatric oncology patients. Pediatr. Blood Cancer 2018, 65, e26937. [CrossRef]

8. Whirl-Carrillo, M.; McDonagh, E.M.; Hebert, J.M.; Gong, L.; Sangkuhl, K.; Thorn, C.F.; Altman, R.B.; Klein, T.E. Pharmacogenomics knowledge for personalized medicine. Clin. Pharmacol. Ther. 2012, 92, 414-417. [CrossRef]

9. U S Food and Drug Administration Home Page. Available online: https://www.fda.gov / (accessed on 25 June 2021).

10. European Medicines Agency. Available online: https://www.ema.europa.eu/ (accessed on 25 June 2021).

11. Pharmaceuticals and Medical Devices Agency. Available online: http:/ / www.pmda.go.jp/english/ (accessed on 25 June 2021).

12. Drugs and Health Products—Canada. Available online: https://www.canada.ca/en/health-canada/services/drugs-healthproducts.html (accessed on 25 June 2021).

13. Clinical Phramacogenetics Implementation Consortium. Available online: https:// cpicpgx.org (accessed on 25 June 2021).

14. Dutch Pharmacogenetics Working Group. Available online: https://knmp.nl (accessed on 25 June 2021).

15. García-Alfonso, P.; Saiz-Rodríguez, M.; Mondéjar, R.; Salazar Blanco, J.; Páez, D.; Borobia Pérez, A.; Safont Aguilera, M.J.; García García, I.; Colomer, R.; García González, X.; et al. Consensus of experts from the Spanish Pharmacogenetics and Pharmacogenomics Society and the Spanish Society of Medical Oncology for the genotyping of DPYD in cancer patients who are candidates for treatment with fluoropyrimidines. Clin. Transl. Oncol. 2021. (submitted, under review).

16. Lee, J.W.; Pussegoda, K.; Rassekh, S.R.; Monzon, J.G.; Liu, G.; Hwang, S.; Bhavsar, A.P.; Pritchard, S.; Ross, C.J.; Amstutz, U.; et al. Clinical Practice Recommendations for the Management and Prevention of Cisplatin-Induced Hearing Loss Using Pharmacogenetic Markers. Ther. Drug Monit. 2016, 38, 423-431. [CrossRef]

17. Aminkeng, F.; Ross, C.J.; Rassekh, S.R.; Hwang, S.; Rieder, M.J.; Bhavsar, A.P.; Smith, A.; Sanatani, S.; Gelmon, K.A.; Bernstein, D.; et al. Recommendations for genetic testing to reduce the incidence of anthracycline-induced cardiotoxicity. Br. J. Clin. Pharmacol. 2016, 82, 683-695. [CrossRef] 
18. Huezo-Diaz Curtis, P.; Uppugunduri, C.R.S.; Muthukumaran, J.; Rezgui, M.A.; Peters, C.; Bader, P.; Duval, M.; Bittencourt, H.; Krajinovic, M.; Ansari, M. Association of CTH variant with sinusoidal obstruction syndrome in children receiving intravenous busulfan and cyclophosphamide before hematopoietic stem cell transplantation. Pharm. J. 2018, 18, 64-69. [CrossRef]

19. Uppugunduri, C.R.; Rezgui, M.A.; Diaz, P.H.; Tyagi, A.K.; Rousseau, J.; Daali, Y.; Duval, M.; Bittencourt, H.; Krajinovic, M.; Ansari, $\mathrm{M}$. The association of cytochrome P450 genetic polymorphisms with sulfolane formation and the efficacy of a busulfan-based conditioning regimen in pediatric patients undergoing hematopoietic stem cell transplantation. Pharm. J. 2014, 14, $263-271$. [CrossRef]

20. Ten Brink, M.H.; van Bavel, T.; Swen, J.J.; van der Straaten, T.; Bredius, R.G.; Lankester, A.C.; Zwaveling, J.; Guchelaar, H.J. Effect of genetic variants GSTA1 and CYP39A1 and age on busulfan clearance in pediatric patients undergoing hematopoietic stem cell transplantation. Pharmacogenomics 2013, 14, 1683-1690. [CrossRef]

21. Yee, S.W.; Mefford, J.A.; Singh, N.; Percival, M.E.; Stecula, A.; Yang, K.; Witte, J.S.; Takahashi, A.; Kubo, M.; Matsuda, K.; et al. Impact of polymorphisms in drug pathway genes on disease-free survival in adults with acute myeloid leukemia. J. Hum. Genet. 2013, 58, 353-361. [CrossRef]

22. Xu, X.; Duan, L.; Zhou, B.; Ma, R.; Zhou, H.; Liu, Z. Genetic polymorphism of copper transporter protein 1 is related to platinum resistance in Chinese non-small cell lung carcinoma patients. Clin. Exp. Pharmacol. Physiol. 2012, 39, 786-792. [CrossRef]

23. Xu, J.L.; Wang, Z.W.; Hu, L.M.; Yin, Z.Q.; Huang, M.D.; Hu, Z.B.; Shen, H.B.; Shu, Y.Q. Genetic variants in the $\mathrm{PI} 3 \mathrm{~K} / \mathrm{PTEN} / \mathrm{AKT} / \mathrm{mTOR}$ pathway predict platinum-based chemotherapy response of advanced non-small cell lung cancers in a Chinese population. Asian Pac. J. Cancer Prev. 2012, 13, 2157-2162. [CrossRef] [PubMed]

24. Xu, X.; Han, L.; Yang, H.; Duan, L.; Zhou, B.; Zhao, Y.; Qu, J.; Ma, R.; Zhou, H.; Liu, Z. The A/G allele of eIF3a rs3740556 predicts platinum-based chemotherapy resistance in lung cancer patients. Lung Cancer 2013, 79, 65-72. [CrossRef] [PubMed]

25. Patiño-García, A.; Zalacaín, M.; Marrodán, L.; San-Julián, M.; Sierrasesúmaga, L. Methotrexate in pediatric osteosarcoma: Response and toxicity in relation to genetic polymorphisms and dihydrofolate reductase and reduced folate carrier 1 expression. J. Pediatr. 2009, 154, 688-693. [CrossRef] [PubMed]

26. Pu, X.; Hildebrandt, M.A.; Lu, C.; Lin, J.; Stewart, D.J.; Ye, Y.; Gu, J.; Spitz, M.R.; Wu, X. PI3K/PTEN/AKT/mTOR pathway genetic variation predicts toxicity and distant progression in lung cancer patients receiving platinum-based chemotherapy. Lung Cancer 2011, 71, 82-88. [CrossRef]

27. Caronia, D.; Patiño-Garcia, A.; Peréz-Martínez, A.; Pita, G.; Moreno, L.T.; Zalacain-Díez, M.; Molina, B.; Colmenero, I.; Sierrasesúmaga, L.; Benítez, J.; et al. Effect of $\mathrm{ABCB} 1$ and $\mathrm{ABCC} 3$ polymorphisms on osteosarcoma survival after chemotherapy: $\mathrm{A}$ pharmacogenetic study. PLoS ONE 2011, 6, e26091. [CrossRef]

28. Low, S.K.; Kiyotani, K.; Mushiroda, T.; Daigo, Y.; Nakamura, Y.; Zembutsu, H. Association study of genetic polymorphism in ABCC4 with cyclophosphamide-induced adverse drug reactions in breast cancer patients. J. Hum. Genet. 2009, 54, 564-571. [CrossRef]

29. Shu, W.; Guan, S.; Yang, X.; Liang, L.; Li, J.; Chen, Z.; Zhang, Y.; Chen, L.; Wang, X.; Huang, M. Genetic markers in CYP2C19 and CYP2B6 for prediction of cyclophosphamide's 4-hydroxylation, efficacy and side effects in Chinese patients with systemic lupus erythematosus. Br. J. Clin. Pharmacol. 2016, 81, 327-340. [CrossRef]

30. Rocha, V.; Porcher, R.; Fernandes, J.F.; Filion, A.; Bittencourt, H.; Silva, W., Jr.; Vilela, G.; Zanette, D.L.; Ferry, C.; Larghero, J.; et al. Association of drug metabolism gene polymorphisms with toxicities, graft-versus-host disease and survival after HLA-identical sibling hematopoietic stem cell transplantation for patients with leukemia. Leukemia 2009, 23, 545-556. [CrossRef]

31. Bray, J.; Sludden, J.; Griffin, M.J.; Cole, M.; Verrill, M.; Jamieson, D.; Boddy, A.V. Influence of pharmacogenetics on response and toxicity in breast cancer patients treated with doxorubicin and cyclophosphamide. Br. J. Cancer 2010, 102, 1003-1009. [CrossRef] [PubMed]

32. Su, H.I.; Sammel, M.D.; Velders, L.; Horn, M.; Stankiewicz, C.; Matro, J.; Gracia, C.R.; Green, J.; DeMichele, A. Association of cyclophosphamide drug-metabolizing enzyme polymorphisms and chemotherapy-related ovarian failure in breast cancer survivors. Fertil. Steril. 2010, 94, 645-654. [CrossRef]

33. Chen, R.L.; Reynolds, C.P.; Seeger, R.C. Neutrophils are cytotoxic and growth-inhibiting for neuroblastoma cells with an anti-GD2 antibody but, without cytotoxicity, can be growth-stimulating. Cancer Immunol. Immunother. 2000, 48, 603-612. [CrossRef] [PubMed]

34. Greenwood, K.L.; Foster, J.H. The safety of dinutuximab for the treatment of pediatric patients with high-risk neuroblastoma. Expert Opin. Drug Saf. 2018, 17, 1257-1262. [CrossRef] [PubMed]

35. Lal, S.; Wong, Z.W.; Sandanaraj, E.; Xiang, X.; Siang Ang, P.C.; Lee, E.J.D.; Chowbay, B. Influence of ABCB1 and ABCG2 polymorphisms on doxorubicin disposition in Asian breast cancer patients. Cancer Sci. 2008, 99, 816-823. [CrossRef] [PubMed]

36. Wojnowski, L.; Kulle, B.; Schirmer, M.; Schlüter, G.; Schmidt, A.; Rosenberger, A.; Vonhof, S.; Bickeböller, H.; Toliat, M.R.; Suk, E.K.; et al. NAD $(\mathrm{P}) \mathrm{H}$ oxidase and multidrug resistance protein genetic polymorphisms are associated with doxorubicin-induced cardiotoxicity. Circulation 2005, 112, 3754-3762. [CrossRef]

37. Lal, S.; Sandanaraj, E.; Wong, Z.W.; Ang, P.C.; Wong, N.S.; Lee, E.J.; Chowbay, B. CBR1 and CBR3 pharmacogenetics and their influence on doxorubicin disposition in Asian breast cancer patients. Cancer Sci. 2008, 99, 2045-2054. [CrossRef]

38. Fan, L.; Goh, B.C.; Wong, C.I.; Sukri, N.; Lim, S.E.; Tan, S.H.; Guo, J.Y.; Lim, R.; Yap, H.L.; Khoo, Y.M.; et al. Genotype of human carbonyl reductase CBR3 correlates with doxorubicin disposition and toxicity. Pharmacogenet. Genom. 2008, 18, 621-631. [CrossRef] 
39. Megías-Vericat, J.E.; Montesinos, P.; Herrero, M.J.; Moscardó, F.; Bosó, V.; Rojas, L.; Martínez-Cuadrón, D.; Rodríguez-Veiga, R.; Sendra, L.; Cervera, J.; et al. Impact of NADPH oxidase functional polymorphisms in acute myeloid leukemia induction chemotherapy. Pharm. J. 2018, 18, 301-307. [CrossRef]

40. Gelderblom, H.; Blay, J.Y.; Seddon, B.M.; Leahy, M.; Ray-Coquard, I.; Sleijfer, S.; Kerst, J.M.; Rutkowski, P.; Bauer, S.; Ouali, M.; et al. Brostallicin versus doxorubicin as first-line chemotherapy in patients with advanced or metastatic soft tissue sarcoma: An European Organisation for Research and Treatment of Cancer Soft Tissue and Bone Sarcoma Group randomised phase II and pharmacogenetic study. Eur. J. Cancer 2014, 50, 388-396. [CrossRef]

41. Windsor, R.E.; Strauss, S.J.; Kallis, C.; Wood, N.E.; Whelan, J.S. Germline genetic polymorphisms may influence chemotherapy response and disease outcome in osteosarcoma: A pilot study. Cancer 2012, 118, 1856-1867. [CrossRef] [PubMed]

42. Relling, M.V.; Nemec, J.; Schuetz, E.G.; Schuetz, J.D.; Gonzalez, F.J.; Korzekwa, K.R. O-demethylation of epipodophyllotoxins is catalyzed by human cytochrome P450 3A4. Mol. Pharmacol. 1994, 45, 352-358. [PubMed]

43. Zelcer, N.; Saeki, T.; Reid, G.; Beijnen, J.H.; Borst, P. Characterization of drug transport by the human multidrug resistance protein 3 (ABCC3). J. Biol. Chem. 2001, 276, 46400-46407. [CrossRef] [PubMed]

44. Huang, R.S.; Duan, S.; Bleibel, W.K.; Kistner, E.O.; Zhang, W.; Clark, T.A.; Chen, T.X.; Schweitzer, A.C.; Blume, J.E.; Cox, N.J.; et al. A genome-wide approach to identify genetic variants that contribute to etoposide-induced cytotoxicity. Proc. Natl. Acad. Sci. USA 2007, 104, 9758-9763. [CrossRef]

45. Shen, Y.; Baker, E.; Callen, D.F.; Sutherland, G.R.; Willson, T.A.; Rakar, S.; Gough, N.M. Localization of the human GM-CSF receptor beta chain gene (CSF2RB) to chromosome 22q12.2->q13.1. Cytogenet. Cell Genet. 1992, 61, 175-177. [CrossRef]

46. Ladenstein, R.; Pötschger, U.; Valteau-Couanet, D.; Luksch, R.; Castel, V.; Yaniv, I.; Laureys, G.; Brock, P.; Michon, J.M.; Owens, C.; et al. Interleukin 2 with anti-GD2 antibody ch14.18/CHO (dinutuximab beta) in patients with high-risk neuroblastoma (HR-NBL1/SIOPEN): A multicentre, randomised, phase 3 trial. Lancet Oncol. 2018, 19, 1617-1629. [CrossRef]

47. Yamane, B.H.; Hank, J.A.; Albertini, M.R.; Sondel, P.M. The development of antibody-IL-2 based immunotherapy with hu14.18-IL2 (EMD-273063) in melanoma and neuroblastoma. Expert Opin. Investig. Drugs 2009, 18, 991-1000. [CrossRef]

48. Shusterman, S.; Naranjo, A.; van Ryn, C.; Hank, J.A.; Parisi, M.T.; Shulkin, B.L.; Servaes, S.; London, W.B.; Shimada, H.; Gan, J.; et al. Antitumor Activity and Tolerability of hu14.18-IL2 with GMCSF and Isotretinoin in Recurrent or Refractory Neuroblastoma: A Children's Oncology Group phase II study. Clin. Cancer Res. 2019, 25, 6044-6051. [CrossRef]

49. Harkey, M.A.; Czerwinski, M.; Slattery, J.; Kiem, H.P. Overexpression of glutathione-S-transferase, MGSTII, confers resistance to busulfan and melphalan. Cancer Investig. 2005, 23, 19-25. [CrossRef]

50. Hodges, L.M.; Markova, S.M.; Chinn, L.W.; Gow, J.M.; Kroetz, D.L.; Klein, T.E.; Altman, R.B. Very important pharmacogene summary: ABCB1 (MDR1, P-glycoprotein). Pharmacogenet. Genom. 2011, 21, 152-161. [CrossRef]

51. Pu, X.; Wang, L.; Chang, J.Y.; Hildebrandt, M.A.T.; Ye, Y.; Lu, C.; Skinner, H.D.; Niu, N.; Jenkins, G.D.; Komaki, R.; et al. Inflammation-related genetic variants predict toxicity following definitive radiotherapy for lung cancer. Clin. Pharmacol. Ther. 2014, 96, 609-615. [CrossRef] [PubMed]

52. Fachal, L.; Gómez-Caamaño, A.; Barnett, G.C.; Peleteiro, P.; Carballo, A.M.; Calvo-Crespo, P.; Kerns, S.L.; Sánchez-García, M.; Lobato-Busto, R.; Dorling, L.; et al. A three-stage genome-wide association study identifies a susceptibility locus for late radiotherapy toxicity at 2q24.1. Nat. Genet. 2014, 46, 891-894. [CrossRef] [PubMed]

53. Roberts, J.K.; Birg, A.V.; Lin, T.; Daryani, V.M.; Panetta, J.C.; Broniscer, A.; Robinson, G.W.; Gajjar, A.J.; Stewart, C.F. Population pharmacokinetics of oral topotecan in infants and very young children with brain tumors demonstrates a role of ABCG2 rs4148157 on the absorption rate constant. Drug Metab. Dispos. 2016, 44, 1116-1122. [CrossRef] [PubMed]

54. Ceppi, F.; Langlois-Pelletier, C.; Gagné, V.; Rousseau, J.; Ciolino, C.; De Lorenzo, S.; Kevin, K.M.; Cijov, D.; Sallan, S.E.; Silverman, L.B.; et al. Polymorphisms of the vincristine pathway and response to treatment in children with childhood acute lymphoblastic leukemia. Pharmacogenomics 2014, 15, 1105-1116. [CrossRef]

55. Egbelakin, A.; Ferguson, M.J.; MacGill, E.A.; Lehmann, A.S.; Topletz, A.R.; Quinney, S.K.; Li, L.; McCammack, K.C.; Hall, S.D.; Renbarger, J.L. Increased risk of vincristine neurotoxicity associated with low CYP3A5 expression genotype in children with acute lymphoblastic leukemia. Pediatr. Blood Cancer 2011, 56, 361-367. [CrossRef]

56. Khabour, O.F.; Alzoubi, K.H.; Firoz, A.S.; Al-Awad, R.M.M. Association between leptin gene rs7799039 polymorphism and lipid profile changes induced by isotretinoin treatment in acne patients. Ther. Clin. Risk Manag. 2018, 14, 949-954. [CrossRef]

57. Lee, J.J.; Wu, X.; Hildebrandt, M.A.T.; Yang, H.; Khuri, F.R.; Kim, E.; Gu, J.; Ye, Y.; Lotan, R.; Spitz, M.R.; et al. Global assessment of genetic variation influencing response to retinoid chemoprevention in head and neck cancer patients. Cancer Prev. Res. 2011, 4, 185-193. [CrossRef] [PubMed]

58. Olivera, G.G.; Yáñez, Y.; Gargallo, P.; Sendra, L.; Aliño, S.F.; Segura, V.; Sanz, M.Á.; Cañete, A.; Castel, V.; De Mora, J.F.; et al. MTHFR and VDR polymorphisms improve the prognostic value of MYCN status on overall survival in neuroblastoma patients. Int. J. Mol. Sci. 2020, 21, 2714. [CrossRef]

59. Nordgard, S.H.; Alnæs, G.I.G.; Hihn, B.; Lingjærde, O.C.; Liestøl, K.; Tsalenko, A.; Sørlie, T.; Lønning, P.E.; Børresen-Dale, A.L.; Kristensen, V.N. Pathway based analysis of SNPs with relevance to 5-FU therapy: Relation to intratumoral mRNA expression and survival. Int. J. Cancer 2008, 123, 577-585. [CrossRef] [PubMed]

60. Findlay, J.M.; Middleton, M.R.; Tomlinson, I. A systematic review and meta-analysis of somatic and germline DNA sequence biomarkers of esophageal cancer survival, therapy response and stage. Ann. Oncol. 2015, 26, 624-644. [CrossRef] [PubMed] 
61. Rubio-San-Simón, A.; Verdú-Amorós, J.; Hladun, R.; Juan-Ribelles, A.; Molero, M.; Guerra-García, P.; Pérez-Martínez, A.; Castañeda, A.; Cañete, A.; de Rojas, T.; et al. Challenges in early phase clinical trials for childhood cancer during the COVID-19 pandemic: A report from the new agents group of the Spanish Society of Paediatric Haematology and Oncology (SEHOP). Clin. Transl. Oncol. 2021, 23, 183-189. [CrossRef] [PubMed]

62. Pritchard-Jones, K.; Dixon-Woods, M.; Naafs-Wilstra, M.; Valsecchi, M.G. Improving recruitment to clinical trials for cancer in childhood. Lancet Oncol. 2008, 9, 392-399. [CrossRef]

63. Mlakar, V.; Curtis, P.H.D.; Uppugunduri, C.R.S.; Krajinovic, M.; Ansari, M. Pharmacogenomics in pediatric oncology: Review of gene-Drug associations for clinical use. Int. J. Mol. Sci. 2016, 17, 1502. [CrossRef]

64. Lin, J.H.; Yamazaki, M. Role of P-glycoprotein in pharmacokinetics: Clinical implications. Clin. Pharmacokinet. 2003, 42, 59-98. [CrossRef]

65. Haag, C.K.B. Ontogeny and Pharmacogenetics: Determinants of Age-Associated Differences in Drng Clearance during Human Development; Erasmus University Rotterdam: Rotterdam, The Netherlands, 2002; ISBN 9067340057.

66. Fernandez, E.; Perez, R.; Hernandez, A.; Tejada, P.; Arteta, M.; Ramos, J.T. Factors and mechanisms for pharmacokinetic differences between pediatrie population and adults. Pharmaceutics 2011, 3, 53-72. [CrossRef]

67. Rao, S.; Uppugunduri, C.; Ansari, M. Commentary: A Myriad Aberrations on Information of Ontogeny of Drug Metabolizing Enzymes in the Pediatric Population: An Obstacle for Personalizing Drug Therapy in the Pediatric Population. Drug Metab. Lett. 2016, 10, 72-74. [CrossRef]

68. Katsila, T.; Patrinos, G.P. The Implications of Metabotypes for Rationalizing Therapeutics in Infants and Children. Front. Pediatr. 2015, 3, 68. [CrossRef]

69. Kim, I.W.; Han, N.; Burckart, G.J.; Oh, J.M. Epigenetic changes in gene expression for drug-metabolizing enzymes and transporters. Pharmacotherapy 2014, 34, 140-150. [CrossRef] [PubMed]

70. Ingelman-Sundberg, M.; Zhong, X.B.; Hankinson, O.; Beedanagari, S.; Yu, A.M.; Peng, L.; Osawa, Y. Potential role of epigenetic mechanisms in the regulation of drug metabolism and transport. Drug Metab. Dispos. 2013, 41, 1725-1731. [CrossRef] [PubMed] 